\title{
Cryptococcus shivajii sp. nov.: A Novel Basidiomycetous Yeast Isolated from Biogas Reactor
}

\author{
Sreenivas Rao Ravella $\cdot$ Stephen A. James • \\ Christopher J. Bond · Ian N. Roberts · Kathryn Cross • \\ Andy Retter $\cdot$ Phil J. Hobbs
}

Received: 30 July 2009/Accepted: 21 August 2009/Published online: 24 September 2009

(C) Springer Science+Business Media, LLC 2009

\begin{abstract}
Five yeast morphotypes were isolated from biogas reactors at North Wyke Research, Okehampton, UK. Out of the five morphotypes, four were identified as known species. In contrast, the fifth morphotype strain, Bio $10^{\mathrm{T}}$, was found to differ from Bullera dendrophila and Kwoniella mangroviensis, its closest phylogenetic neighbours, by $2.6-2.9 \%$ with respect to the nucleotide sequence of the D1/D2 domain of the 26S rRNA gene and by 5.6$6.2 \%$ with respect to the internal transcribed spacer 1 (ITS1)-5.8S rRNA gene-ITS2 region. Bio10 ${ }^{\mathrm{T}}$ also differs from these two species by a number of phenotypic characteristics. Thus, based on the phenotypic differences and phylogenetic analysis, strain Bio10 ${ }^{\mathrm{T}}$ is assigned the status of a new species of Cryptococcus, for which the name Cryptococcus shivajii sp. nov. is proposed. The type strain is $\operatorname{Bio} 10^{\mathrm{T}}\left(\mathrm{NCYC} 3541^{\mathrm{T}}=\operatorname{CBS} 11374^{\mathrm{T}}\right)$.
\end{abstract}

\section{Introduction}

Biogas reactors have a vast diversity of microorganisms, including novel microbes like Methanobrevibacter acididurans sp. nov. and yeasts [13, 18]. These organisms play a vital role in biomass hydrolysis, volatile fatty acids

S. R. Ravella · A. Retter · P. J. Hobbs (ه)

North Wyke Research, Okehampton, Devon EX20 2SB, UK

e-mail: phil.hobbs@bbsrc.ac.uk

S. A. James · C. J. Bond · I. N. Roberts

National Collection of Yeast Cultures (NCYC), Institute of Food

Research, Norwich Research Park, Colney, Norwich, UK

K. Cross

Image and Microscopy Group (IMG), Institute of Food

Research, Norwich Research Park, Colney, Norwich, UK production and biomethane production [7, 8]. A complex microbial community is involved in the different steps of the anaerobic digestion (AD) process $[14,26]$. Yeasts are known to accelerate the decomposition rate of anaerobic biological treatment [16]. There are several reports available on the microbial communities that produce methane $[10,11]$. Microbes produce enzymes with a suitable substrate such as energy crops or plant material when subjected to AD. Energy crop for biogas plants are usually ensilaged for conservation and storage [22]. Ensilaging involves chopping and compacting the fresh crop in silos and then covering with an airtight membrane. The $\mathrm{pH}$ reduction (to about $\mathrm{pH} 4$ ), performed through an autochthonic mixed population of lactic acid bacteria and yeasts, stabilises the plant material for storage for over a year before being used to produce biogas. Yeasts and yeast-like fungi utilising plant material release extracellular endoxylanases that hydrolyse plant material [1]. As yet, there have been no reports available on yeasts from biogas reactors, and therefore, this study was conducted to isolate yeasts from biogas reactors especially from the hydrolysis stage.

\section{Materials and Methods}

Isolation of the Organism, Media and Maintenance

Samples were collected from laboratory-scale biogas reactors operating at North Wyke Research, Okehampton, Devon, UK. A small aliquot of the sample $(50 \mu \mathrm{l})$ was plated on yeast-malt agar medium (YM) containing peptone $\left(5 \mathrm{~g}^{-1}\right)$, yeast extract $\left(3 \mathrm{~g}^{-1}\right)$, malt extract $\left(3 \mathrm{~g} \mathrm{l}^{-1}\right)$, dextrose $\left(10 \mathrm{~g} \mathrm{l}^{-1}\right)$ and agar $\left(15 \mathrm{~g}^{-1}\right)$ supplemented with chloramphenicol $\left(0.1 \mathrm{~g} \mathrm{l}^{-1}\right)$. The plates were incubated at $28^{\circ} \mathrm{C}$ for 5 days. The yeast colonies that 
subsequently appeared on the plates were grouped initially based on their colony morphology, with between 30 and 40 colonies of each morphotype isolated. Three to five representatives of each morphotype were purified by repeated sub-culturing on Rose Bengal-Chloramphenicol plates containing peptone $\left(5.0 \mathrm{~g} \mathrm{l}^{-1}\right)$, dextrose $\left(10 \mathrm{~g} \mathrm{l}^{-1}\right)$ monopotassium phosphate $\left(1.0 \mathrm{~g} \mathrm{l}^{-1}\right)$, magnesium sulphate $\left(0.5 \mathrm{~g} \mathrm{l}^{-1}\right)$, Rose Bengal $\left(0.05 \mathrm{~g} \mathrm{l}^{-1}\right)$, chloramphenicol $\left(0.1 \mathrm{~g} \mathrm{l}^{-1}\right)$ and agar $\left(15.5 \mathrm{~g} \mathrm{l}^{-1}\right)$. For routine sub-culturing and maintenance, the strains were grown either on YM agar or in YM broth at $28^{\circ} \mathrm{C}$.

\section{Examination of Growth Characteristics}

The morphological, physiological and biochemical characteristics of $B i o 10^{\mathrm{T}}$ were determined according to the standard methods as described by Yarrow [25]. Growth temperature was determined by cultivation on YM agar. Sporulation tests were performed on corn meal agar (CMA), Gorodkowa agar, potassium acetate agar, potato dextrose agar (PDA) and YM agar, and plates were incubated at $25^{\circ} \mathrm{C}$ for 3 weeks. The presence or absence of ballistoconidia was determined on inverted CMA plates kept at room temperature and monitored over a 4-week period.

\section{Isolation and Purification of Nuclear DNA}

Nuclear DNA was isolated from stationary phase-grown cultures according to the method of Makimura et al. [12]. For this purpose, cells were harvested by centrifugation and the cell pellet suspended in lysis buffer [100 mM Tris-HCl (pH 8.0) containing $2 \%$ Triton X-100, $1 \%$ SDS and $1 \mathrm{mM}$ EDTA] and then lysed by vortexing with 0.3 g glass beads $(0.45-0.52 \mathrm{~mm}$ in diameter, Sigma, Poole, UK). The cell lysate was used to prepare DNA.

\section{DNA Sequence Analysis}

The D1/D2 domain of the 26S rRNA gene and the ribosomal internal transcribed spacer (ITS) region were PCRamplified from yeast cell suspensions of Bio $10^{\mathrm{T}}$ following the method as described by James et al. [6]. The D1/D2 domain was amplified using primers NL1 and NL4 [15], and the entire ITS region, including the 5.8S rRNA gene, using primers ITS5 and ITS4 [24]. Amplified fragments were analysed by $1.0 \%$ agarose gel electrophoresis, purified with a QIAquick PCR purification kit (QIAGEN, Crawley, UK) as per the manufacturer's instructions, and cycle sequenced directly using an ABI BigDye terminator cycle sequencing kit, version 3.1 (Applied Biosystems, Warrington, UK). The D1/D2 fragment was sequenced using the external amplification primers NL1 and NL4, while the ITS fragment was sequenced using the external amplification primer ITS4 and the internal primers ITS1 (in place of ITS5), ITS2 and ITS3 [24]. All purified sequencing reaction mixes were sequenced using an $\mathrm{ABI}$ PRISM 3730 capillary sequencer (Applied Biosystems, Warrington, UK) at the John Innes Centre Genome Laboratory in Norwich. The two Bio $10^{\mathrm{T}}$ ribosomal DNA sequences were deposited in the EMBL database under the accession numbers FM212443 (D1/D2 domain) and FM212571 (ITS region).

Sequence similarity searches were conducted using EMBL FASTA. Sequences of closely related taxa were retrieved and aligned and corrected using CLUSTAL_X [23]. The alignment files were saved with ".phy" extension. Dendrograms were constructed using the PhyML program [5, 17], using 100 replicates of non-parametric bootstrap analysis, GTR model of nucleotide substitution and four substitution rate categories [3].

\section{Results and Discussion}

Isolation on YM agar plates yielded more than 30 yeast colonies on each plate which could be distinguished into five different morphotypes (represented by Bio2, Bio5, Bio6, Bio10 and Bio12) based on colony morphology. Four morphotypes, Bio2, Bio5, Bio6 and Bio12, identified based on D1/D2 analysis were Hanseniaspora uvarum, Trichosporon coremiiforme, Rhodotorula glutinis var. dairenensis and Yarrowia lipolytica, respectively.

The fifth strain Bio10 ${ }^{\mathrm{T}}$ (FM212443) differed from Bullera dendrophila CBS $6074^{\mathrm{T}}$ (AF189870) and Kwoniella mangroviensis $\mathrm{CBS} 8507^{\mathrm{T}}$ (AF444742), its closest phylogenetic neighbours, by 2.6 and $2.9 \%$ with respect to the nucleotide sequence of the D1/D2 domain of the $26 \mathrm{~S}$ rRNA gene (Fig. 1), and by 5.6-6.2\% with respect to the internal transcribed spacer 1 (ITS1)-5.8S rRNA gene-ITS2 region. Kwoniella mangroviensis (Tremellales, Basidiomycota), a teleomorphic species isolated from mangrove regions of the Florida Everglades and the Bahamas, presumably contributes to the food web via decomposition of organic materials [21]. Recently, Cryptococcus pinus sp. nov., an anamorphic basidiomycetous species isolated from pine litter was described, and (phylogenetically) assigned to the Kwoniella clade [4]. Bio $10^{\mathrm{T}}$ differs from Cryptococcus pinus by $5.0 \%$ with respect to the nucleotide sequence of the D1/D2 domain of the 26S rRNA gene. Bio $10^{\mathrm{T}}$ is also phylogenetically distinct from other Tremellales displaying close relationships to the species Cryptococcus bestiolae and Cryptococcus dejecticola isolated from frass of the litchi fruit borer. Phylogenetic analysis based on the internal transcribed spacer 1 (ITS1)-5.8S rRNA gene-ITS2 nucleotide sequence indicates that 


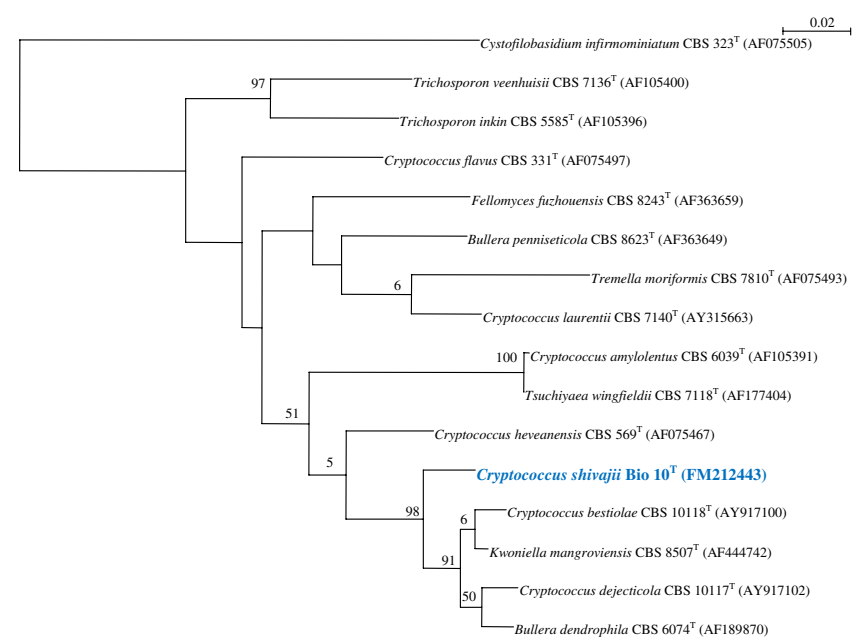

Fig. 1 Neighbour-joining phylogenetic tree based on sequences of the D1/D2 domain of the 26S rRNA gene showing the relationship of Cryptococcus shivajii $\mathrm{Bio} 10^{\mathrm{T}}$ with other member species of the class Tremellomycetes. The tree was constructed using the PhyML program. Bootstrap values $\geq 50 \%$, determined from 100 replicates, are shown at branch nodes. Bar: two base substitutions per 100

Bio10 $^{\mathrm{T}}$ (FM212571) also differs from Bullera dendrophila CBS $6074^{\mathrm{T}}$ (AF444443) isolated from frass of buprestid larvae in Dichrostachys cinerea, Kwoniella mangroviensis CBS $8507^{\mathrm{T}}$ (AF444646), Cryptococcus bestiolae CBS $10118^{\mathrm{T}}$ (AY917101), Cryptococcus dejecticola CBS $10117^{\mathrm{T}}$ (AY917103) and Cryptococcus heveanensis CBS $569^{\mathrm{T}}$ (AF444301) (Fig. 1). Phenotypic differences were compared between Bio10 ${ }^{\mathrm{T}}$ and its two closest relatives, namely, Bullera dendrophila and Kwoniella mangroviensis (Table 1).

Table 1 Phenotypic characteristics that differentiate Cryptococcus shivajii Bio10 ${ }^{\mathrm{T}}$ from Bullera dendrophila and Kwoniella mangroviensis

\begin{tabular}{|c|c|c|c|}
\hline $\begin{array}{l}\text { Biochemical } \\
\text { characteristics }\end{array}$ & $\begin{array}{l}\text { Cryptococcus } \\
\text { shivajii } \\
\text { Bio } 10^{\mathrm{T}}\end{array}$ & $\begin{array}{l}\text { Bullera } \\
\text { dendrophila }\end{array}$ & $\begin{array}{l}\text { Kwoniella } \\
\text { mangroviensis }\end{array}$ \\
\hline \multicolumn{4}{|l|}{ Assimilation test } \\
\hline L-Sorbose & - & - & $\mathrm{s}$ \\
\hline Raffinose & + & - & $\mathrm{v}$ \\
\hline Starch & $\mathrm{w}$ & + & $\mathrm{v}$ \\
\hline Erythritol & - & - & $\mathrm{v}$ \\
\hline Myo-inositol & + & $\mathrm{s}$ & + \\
\hline $\begin{array}{l}\text { D-Glucono-1,5- } \\
\text { lactone }\end{array}$ & + & + & $\mathrm{w}$ \\
\hline Ethylamine & - & + & + \\
\hline Cadaverine & + & - & + \\
\hline Growth at: $30^{\circ} \mathrm{C}$ & - & $\mathrm{v}$ & + \\
\hline
\end{tabular}

${ }^{a}$ Data taken from [2]

b Data taken from [21]

Growth responses: + positive, - negative, s: slow positive, v: variable, w: weak positive

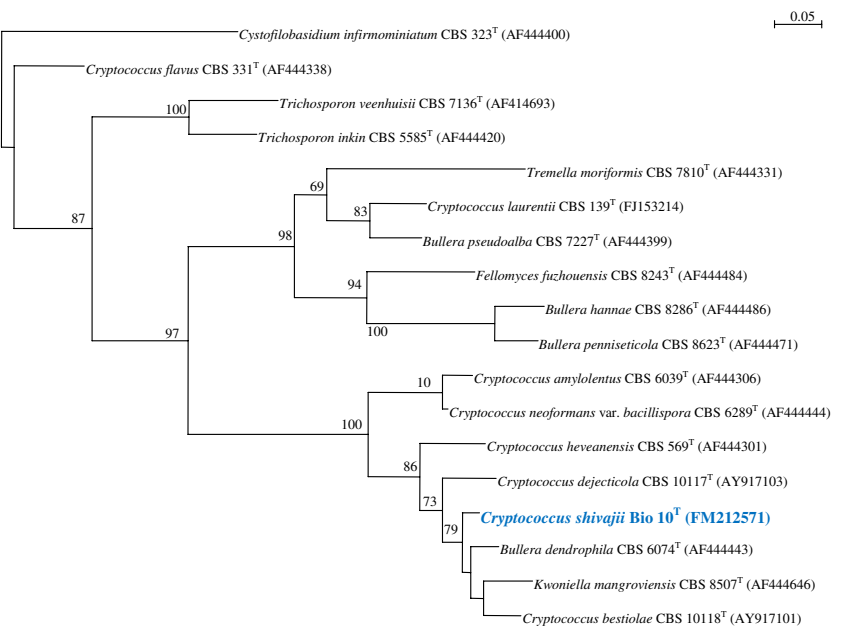

nucleotides. Neighbour-joining phylogenetic tree based on ITS1/5.8S rDNA/ITS2 sequences showing the relationship of strain Bio $10^{\mathrm{T}}$ within the class Tremellomycetes. The tree was constructed using the PhyML program. Numbers: shown at nodes are bootstrap values. Bar: five nucleotide substitutions per 100 nucleotides. Bootstrap values $\geq 50 \%$, determined from 100 replicates, are shown

Although Bio $10^{\mathrm{T}}$ and Kwoniella mangroviensis are phenotypically very similar, the two species can be distinguished from one another on the basis of ethylamine assimilation and maximum growth temperature. In contrast, Bio10 ${ }^{\mathrm{T}}$ differs from Bullera dendrophila in at least five phenotypic characteristics (Table 1). Scanning electron microscopy revealed that Bio $10^{\mathrm{T}}$ cultures when grown either in $\mathrm{YM}$ broth or on YM agar for 2 days at $20^{\circ} \mathrm{C}$ exhibit a very interesting and distinct phenotypic characteristic, namely, a fibrillar-like cell surface (Fig. 2a).

Thus, based on the phenotypic differences and phylogenetic analysis, strain Bio10 ${ }^{\mathrm{T}}$ is assigned the status of a new species of Cryptococcus, for which the name Cryptococcus shivajii sp. nov. is proposed. The type strain is Bio $10^{\mathrm{T}}\left(\mathrm{NCYC} 3541^{\mathrm{T}}=\mathrm{CBS} 11374^{\mathrm{T}}\right)$. The recognition of Bio10 $0^{\mathrm{T}}$ as a different species is in accordance with the criteria that strains with $>1 \%$ substitution in the D1/D2 domain [9] and a similar extent of variation in the ITS region [20] typically represent new species.

Latin Diagnosis of Cryptococcus shivajii sp. nov.

Ravella et al.

In medio liquido $\mathrm{YM}$ post dies 2 ad $25^{\circ} \mathrm{C}$, cellulae vegetativae globosae aut oblongae $\left(5-6 \times 6-8 \mu^{2}\right)$, cellulae singulae, binae et aggregatae. Per gemmationem multipolarem reproducentes. Post 1 mensem ad $25^{\circ} \mathrm{C}$ pellicula et sedimentum formantur. In agaro YM post dies 2 ad $25^{\circ} \mathrm{C}$, colonia butyrosa. D-glucosum, sucrosum, D-maltosum, D-galactosum, cellobiosum, lactosum, raffinosum, D-xylosum non fermentantur. Assimilantur D-glucosum, D-galactosum, 

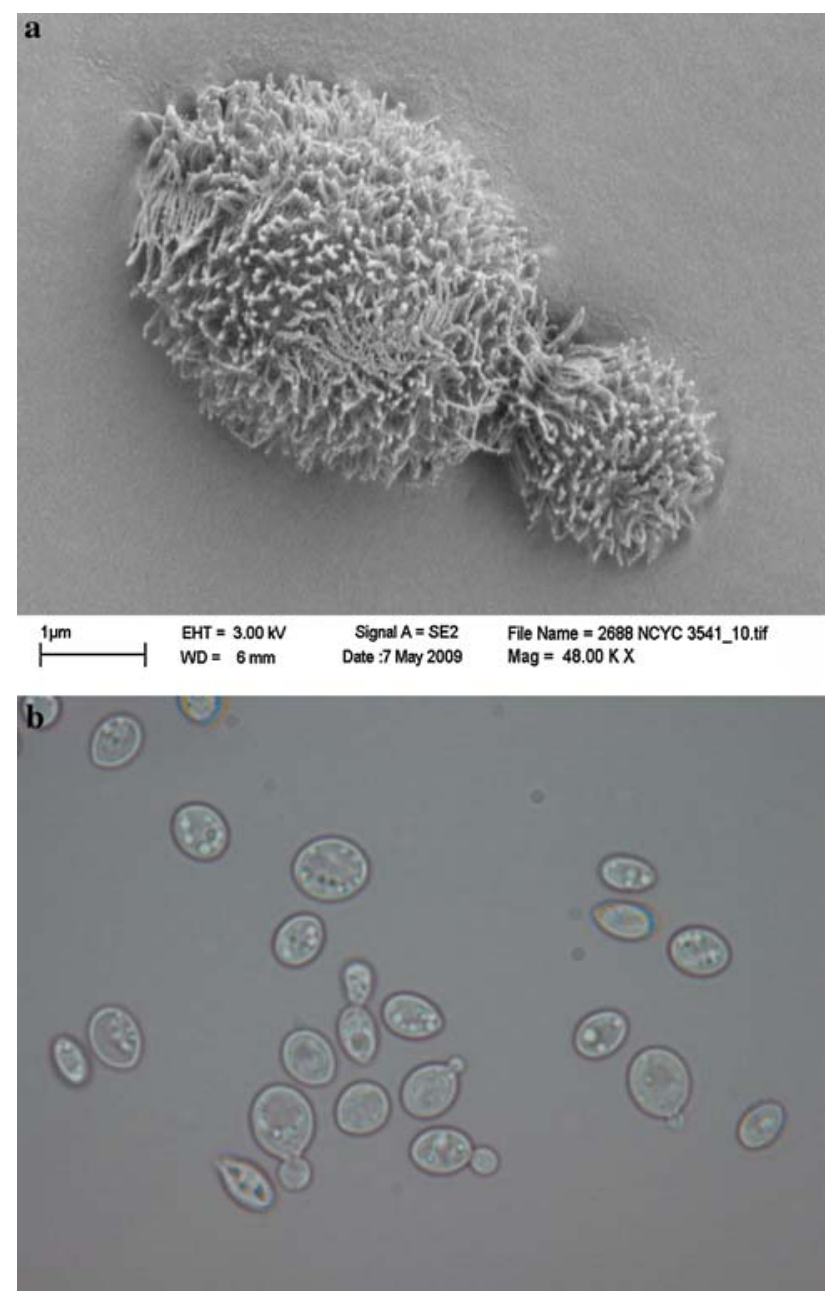

Fig. 2 a Scanning electron microscope image of vegetative cells of Cryptococcus shivajii NCYC $3541^{\mathrm{T}}$ grown in YM broth for 2 days at $20^{\circ} \mathrm{C}$ with agitation, showing the fibrillar-like cell surface phenotype. b Photomicrograph of vegetative cells of Cryptococcus shivajii NCYC $3541^{\mathrm{T}}$ grown on YM agar for 3 days at $20^{\circ} \mathrm{C}$

sucrosum, D-maltosum, cellobiosum, trehalosum, lactosum, raffinosum, melezitosum, amylum, D-xylosum, L-arabinosum, D-arabinosum, D-ribosum, L-rhamnosum, ethanolum, glycerolum, ribitolum, galactitolum, D-mannitolum, D-glucitolum, salicinum, D-glucono-1,5-lactonum, xylitolum, natrium succinatum et natrium citratum (infirme). Non-assimiluntur L-sorbosium, melibiosum, erythritolum, inulinum, DL-lactatum, methanolum. Assimilantur lysinum, cadaverinum, ammonium sulphatum. Non assimilantur ethylaminum, nitratum, kalium nitritum, Non crescit in medio $0.1 \%$ cycloheximido addito. Reactio Diazonii coerulei B positive, Ureum finditur.

Typus: Bio $10^{\mathrm{T}}\left(=\mathrm{NCYC} 3541^{\mathrm{T}}=\mathrm{CBS} 11374^{\mathrm{T}}\right)$, designat stirpem typicum. Isolata ex biogas reactor, North Wyke Research, Okehampton, Devon, UK. depositata in Collectione Culturarum NCYC, UK.
Etym: shivajii (shi. Vaji'i.i; Lat., gen. mas. n) 'of shivaji', to recognise the contributions of Sisinthy Shivaji, a scientist who has contributed significantly to the biodiversity study of psychrophiles and the molecular basis of survival [19].

Description of Cryptococcus shivajii sp. nov.

Ravella et al.

In liquid media (YM) after 2 days at $25^{\circ} \mathrm{C}$, vegetative cells are oval to long ovoid (5-6 $\left.\times 6-8 \mu \mathrm{m}^{2}\right)$, occur singly, in pairs or in groups (Fig. 2b). Budding is multilateral. After 1 month at $25^{\circ} \mathrm{C}$, pellicle and sediment formation takes place. On YM agar after 2 days at $25^{\circ} \mathrm{C}$, colonies are smooth, butyrous, glistening and cream coloured with entire margin. Sugars are not fermented. D-glucose, galactose, sucrose, maltose, cellobiose, trehalose, lactose, raffinose, melezitose, starch (weak), D-xylose, L-arabinose, D-arabinose, D-ribose (weak), L-rhamnose, ethanol, glycerol, ribitol, galactitol, D-mannitol, D-glucitol, xylitol, $\alpha$ methyl D-glucoside (very weak), glucono-D-lactone, succinic acid, inositol, and citric acid (weak) are assimilated, whereas L-sorbose, melibiose, inulin, erythritol, DL-lactic acid, D-glucosamine and methanol are not assimilated. The nitrogen compounds cadaverine, L-lysine and ammonium sulphate are assimilated, whereas ethylamine and potassium nitrate are not assimilated. Bio $10^{\mathrm{T}}$ does not grow on $50 \%(\mathrm{w} / \mathrm{w})$ glucose yeast extract agar, or in $16 \% \mathrm{NaCl}$ SPGYE medium. The strain is sensitive to $0.1 \%$ cycloheximide. Urea is hydrolysed (weakly), and the diazonium blue $B$ reaction is positive.

The type strain is Bio $10^{\mathrm{T}}$ (= NCYC $3541^{\mathrm{T}}=\mathrm{CBS}$ $11374^{\mathrm{T}}$ ), isolated from biogas reactor, North Wyke Research, Okehampton, Devon, UK.

Acknowledgements We would like to thank Biotechnology and Biological Sciences Research Council (BBSRC) UK for India Partnering Award and EU for Agro biogas project. North Wyke Research is an institute of the Biotechnology and Biological Sciences Research Council of UK. We thank Dr Mary Parker for her kind advice and assistance with the imaging at the Institute of Food Research, Norwich Research Park, Colney, Norwich, UK. Sreenivas would like to thank Waqar Ali, University of Oxford, UK for his bioinformatics support during bioinformatics course at University of Oxford, UK.

\section{References}

1. Bhadra B, Rao SR, Kumar PS, Sarkar PK, Shivaji S (2008) Yeasts and yeast like fungi associated with the bark of trees: diversity of yeasts and identification of yeasts producing extracellular endoxylanases. Curr Microbiol 56:489-494

2. Boekhout T, Nakase T (1998) Bullera Derx. In: Kurtzman CP, Fell JW (eds) The yeasts, a taxonomic study, 4th edn. Elsevier, Amsterdam, pp 731-741

3. Felsenstein J (1985) Confidence limits on phylogenies: an approach using bootstrap. Evolution 39:783-791 
4. Golubev W, Pfeiffer I, Tomashevskaya MA (2008) Cryptococcus pinus sp. Nov., an anamorphic basidiomycetous yeast isolated from pine litter. Int J Syst Evol Microbiol 58:1968-1971

5. Guindon S, Gascuel O (2003) A simple, fast, and accurate algorithm to estimate large phylogenies by maximum likelihood. Syst Biol 52:696-704

6. James SA, Collins MD, Roberts IN (1996) Use of an rRNA internal transcribed spacer region to distinguish phylogenetically closely related species of the genera Zygosaccharomyces and Torulaspora. Int J Syst Bacteriol 46:189-194

7. Klockea M, Mahnerta P, Mundta K, Souidia K, Linke B (2007) Microbial community analysis of a biogas-producing completely stirred tank reactor fed continuously with fodder beet silage as mono-substrate. Syst Appl Microbiol 30:139-151

8. Klockea M, Nettmanna E, Bergmanna I, Mundta K, Souidia K, Mummea J, Linkea B (2008) Characterization of the methanogenic Archaea within two-phase biogas reactor systems operated with plant biomass. Syst Appl Microbiol 31:190-205

9. Kurtzman CP, Robnett CJ (1998) Identification and phylogeny of ascomycetous yeasts from analysis of nuclear large subunit (26S) ribosomal DNA partial sequences. Antonie Van Leeuwenhoek 73:331-371

10. Leclerc M, Delbes C, Moletta R, Godon JJ (2001) Single strand conformation polymorphism monitoring of 16S rDNA Archaea during start-up of an anaerobic digester. FEMS Microbiol Ecol 34:213-220

11. Leclerc M, Delgènes JP, Godon JJ (2004) Diversity of the archaeal community in 44 anaerobic digesters as determined by single strand conformation polymorphism analysis and $16 \mathrm{~S}$ rDNA sequencing. Environ Microbiol 8:809-819

12. Makimura K, Murayama SY, Yamaguchi H (1994) Detection of a wide range of medically important fungi by the polymerase chain reaction. J Med Microbiol 40:358-364

13. Martinez-Garcia G, Johnson AC, Bachmann RT, Williams CJ, Burgoyne A, Edyvean RGJ (2009) Anaerobic treatment of olive mill waste water and piggery effluents fermented with Candida tropicalis. J Hazard Mater 164:1398-1405

14. McHugh S, Carton M, Mahony T, O'Flaherty V (2003) Methanogenic population structure in a variety of anaerobic bioreactors. FEMS Microbiol Lett 219:297-304

15. O’Donnell K (1993) Fusarium and its near relatives. In: Reynolds DR, Taylor JW (eds) The fungal holomorph: mitotic, meiotic and pleomorphic speciation in fungal systematics. CAB International, Wallingford, pp 225-233

16. Olcay O, Kocasoy G (2004) Acceleration of the decomposition rate of anaerobic biological treatment. J Environ Sci Health 39:1083-1093

17. Saitou N, Nei M (1987) The neighbor-joining method: a new method for reconstructing phylogenetic trees. Mol Biol Evol 4:406-425

18. Savant DV, Shouche YS, Prakash S, Ranade DR (2002) Methanobrevibacter acididurans sp. nov., a novel methanogen from a sour anaerobic digester. Int J Syst Evol Microbiol 52:1081-1087

19. Saxena DM (2007) Dr. S. Shivaji-a zoologist turned microbiologist. Ind J Microbiol 47:94-95

20. Scorzetti G, Fell JW, Fonseca A, Statzell-Tallman A (2002) Systematics of basidiomycetous yeasts: a comparison of large subunit D1/D2 and internal transcribed spacer rDNA regions. FEMS Yeast Res 2:495-517

21. Statzell-Tallman A, Belloch C, Fell JW (2008) Kwoniella mangroviensis gen. nov., sp. nov. (Tremellales, Basidiomycota), a teleomorphic yeast from mangrove habitats in the Florida Everglades and Bahamas. FEMS Yeast Res 8:103-113

22. Strayer RF, Finger BW, Alazraki MP (1997) Evaluation of an anaerobic digestion system for processing celss crop residues for resource recovery. Adv Space Res 20:2009-2015

23. Thompson JD, Gibson TJ, Plewniak F, Jeanmougin F, Higgins DG (1997) The CLUSTAL_X windows interface: flexible strategies for multiple sequence alignment aided by quality analysis tools. Nucleic Acids Res 25:4876-4882

24. White TJ, Bruns T, Lee S, Taylor J (1990) Amplification and direct sequencing of fungal ribosomal RNA genes for phylogenetics. In: Innis MA, Gelfand DH, Sninsky JJ, White TJ (eds) PCR protocols: a guide to methods and applications. Academic Press, San Diego, pp 315-322

25. Yarrow D (1998) Methods for the isolation, maintenance and identification of yeasts. In: Kurtzman CP, Fell JW (eds) The yeasts, a taxonomic study, 4th edn. Elsevier, Amsterdam, pp 77100

26. Zumstein E, Moletta R, Godon JJ (2000) Examination of two years of community dynamics in an anaerobic bioreactor using fluorescence polymerase chain reaction (PCR) single-strand conformation polymorphism analysis. Environ Microbiol 2: $69-78$ 